\title{
Pre-service Teachers' perceptions on instant messaging and orthographic competence
} Percepções dos professores em formação sobre mensagens instantâneas e competência ortográfica

\section{Francisco Núñez-Román (D) *1, Alejandro Gómez-Camacho (iD ${ }^{\dagger 1}$, María Constanza Errázuriz-Cruz (D) $\ddagger 2$ and Juan Antonio Núñez-Cortés (iD §3}

\author{
${ }^{1}$ University of Seville, Faculty of Education Sciences, Department of Language and Literature \\ Teaching, Seville, Spain. \\ ${ }^{2}$ Pontificia Universidad Católica de Chile, Campus Villarrica, Villarrica, Chile. \\ ${ }^{3}$ Autonomous University of Madrid, Faculty of Teacher Training and Education, Department of \\ Philologies and its Didactics, Madrid, Spain.
}

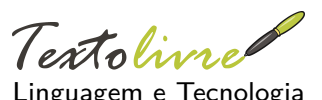

DOI: $10.35699 / 1983-$

3652.2021.34141

\section{Session:}

Articles

Corresponding author: Francisco Núñez-Román

Section Editor:

Daniervelin Pereira

Layout editor:

Leonado Araújo

Received on:

May 23, 2021

Accepted on:

July 1, 2021

Published on:

March 22, 2022

This work is licensed under a "CC BY 4.0" license. () (i)

\begin{abstract}
This work examines the perception held by pre-service teachers of Spanish in Chile and Argentina of the digital written norm in IM, together with their opinion regarding the influence of textisms on secondary students' acquisition of orthographic competence. The study uses a transactional approach based on surveys and uses and applies a descriptive non-experimental design. Results, when compared with studies for the European Spanish variant, showed that pre-service teachers in Chile and Argentina considered the use of textisms as harmful to secondary students' development of orthographic competence, despite their own frequent use of textisms. However, one of the main findings is a certain degree of tolerance of specific types of textisms in digital writing, as was a more integrative approach to those written variables on the part of participants in Argentina.
\end{abstract}

Keywords: Spanish. Spelling. Teacher education training. Social media.

\section{Resumo}

Este trabalho examina a percepção que os professores espanhol em formação no Chile e na Argentina têm da norma escrita digital em mensagens instantâneas, juntamente com sua opinião sobre a influência dos textismos na aquisição de competência ortográfica por parte dos alunos do ensino médio. $O$ estudo utiliza uma abordagem transacional baseada em pesquisas e usos e aplica um design descritivo não experimental. Os resultados, quando comparados com estudos da variante espanhola européia, mostraram que professores de pré-serviço no Chile e na Argentina consideraram o uso de textos como prejudicial ao desenvolvimento da competência ortográfica dos alunos do ensino médio, apesar de seu próprio uso frequente de textos. Entretanto, uma das principais conclusões é um certo grau de tolerância de tipos específicos de textos na escrita digital, assim como uma abordagem mais integrativa dessas variáveis escritas por parte dos participantes na Argentina.

Palavras-chave: Espanhol. Ortografia. Formação de professores. Redes sociais.

\section{Introduction}

According to the Latinobarómetro database (CORPORACIÓN LATINOBARÓMETRO, 2018), 60\% of Latin Americans are frequent users of social networks and instant messaging (IM). Chile and Argentina are two of the countries with the highest incidence of use. In fact, 80\% of Argentinians and $76 \%$ of Chileans identified as regular WhatsApp users, which was the most popular instant messaging service. The next most used were Facebook Messenger (68\% of users in Chile and 67\% Argentina) and Instagram (29\% of users in Argentina and $27 \%$ in Chile) (CHEVALIER, 2019). Unquestionably, IM is the most used internet service in the Spanish-speaking world and, consequently, it is the medium by which texts are most frequently written in Spanish (MARTíN, 2016).

\footnotetext{
*Email: fnroman@us.es

†Email: agomez21@us.es

‡Email: cerrazuc@uc.cl

§mail: juanantonio.nunnez@uam.es
} 
Text messages have evolved into a new writing code, which has been called textese (JOHNSON, 2015) as well as digitalk (TURNER, 2010). The employment of this recently developed code in IM is not a juvenile alternative jargon (BETTI, 2006) or a linguistic prank, but a way of communicating that could, in fact, impact on conventional writing in Spanish (ALONSO; PEREA, 2008; MAS ÁLVAREZ; ZAS VARELA, 2012), and hence, on the way in which writing is taught. Even though 500 million people communicate in Spanish, most of them in South America, the pedagogical implications deriving from the incorporation of textese into day-to-day communications have not been given sufficient attention in the Latin American context.

\section{$1.1 \mathrm{IM}$ and Language}

IM has created a new code which is mainly characterized by its brevity and speed, the use of paralinguistic restitution, and phonological approximation (THURLOW; POFF, 2013; TURNER et al., 2014). Textisms, which are non-normative elements using characters that are not included in the standard norm, are among the main features of textese (JOHNSON, 2015).

Textisms comprise a diverse group of orthographic practices in Spanish: from the suppression of silent letters ( $h$, for example), diagraph simplification (for example, II, ch, qu, gu), simplification of graphemes representing the same phoneme (for example, $b$ instead of $v$, I instead of $y$, or $k$ instead of c or qu), or vowel suppressions, to writing number and mathematical symbols which are homophonous and using letters by their name (for example, $x,+, t$, and 2 , instead of por, más, de, te and dos) (GOMÉZ-CAMACHO; HUNT-GÓMEZ; VALVERDE-MACÍAS, 2018).

Research of the main western languages has arrived at different results for each. The style of text messages in English has been profusely described by Thurlow (2003), Crystal (2008), Plester, Wood, and Joshi (2009), Kemp and Bushnell (2011), De Jonge and Kemp (2012), Lyddy et al. (2014), Wood et al. (2014), Waldron, Wood, and Kemp (2017), and Kemp and Grace (2017). Studies by Bouillaud, Chanquoy, and Gombert (2007) for the French language compared textisms to standard orthography. Subsequently, Bernicot et al. (2014) distinguished two different groups of textisms: ones based on the correspondence between grapheme and morpheme (that is, those following the written standard norm), and ones that were not. That differentiation was confirmed by the results of recent studies of the perception of the digital norm for Italian (GOMÉZ-CAMACHO; NÚÑEZ-ROMÁN; PERERA-RODRÍGUEZ, 2016) and Portuguese (GOMÉZ-CAMACHO; LOPES, 2017). In a recent study, Androutsopoulos and Busch (2021) pointed out that the practices of non-formal writing typical of IM and social networks coexist with formal and academic writing practices and are configured as complementary to the norm, which has now been 'extended by fluid and local conventions that emerge in informal digital practices' (ANDROUTSOPOULOS; BUSCH, 2021, p. 8).

With regard to Peninsular Spanish, there is an increasing number of publications describing the characteristics of textese (CALERO, 2014; CAURCEL DÍAZ; Î̃̃IGUEZ DEL RÍO; GÓMEZ HIDALGO, 2013; DOMÍNGUEZ CUESTA, 2005; GALÁN RODRÍGUEZ, 2002; LLISTERRI, 2002; MANCERA RUEDA, 2016; MAS ÁLVAREZ; ZAS VARELA, 2012; VÁZQUEZ-CANO; MENGUAL-ANDRÉS; ROIG-VILA, 2015). However, this area has barely been explored in the Latin American context, with a few notable exceptions. Giraldo Giraldo, Ríos Londoño, and Cardona Cifuentes (2018) explored Colombian students' perception of textisms, who considered the digital norm to be distant the academic norm and heavily determined by the communication medium; Cantamutto (2018, 2019), and Flores-Salgado and Castineira-Benitez (2018) analysed the digital discourse from a pragmatic perspective in Argentina and Mexico, respectively, and also, Cantamutto and Vela Delfa $(2018,2019)$, who compared the use of multimodal elements in Spain and Argentina.

Textisms were categorised into a taxonomy for the Spanish language in previous studies by GomézCamacho (2007), Goméz-Camacho, Hunt-Gómez, and Valverde-Macías (2018) and Hunt-Gómez, Núñez-Román, and Gómez-Camacho (2020). Considering these previous models, the present study offers a codification of textisms divided into repetitions, omissions, non-normative graphemes, lexical textisms and multimodal elements (Table 1). The classification of textisms in Spanish created a framework structured in three different levels: phonetic-phonological, lexical-semantic, and multimodal. 
Table 1. Category of non-standard spelling.

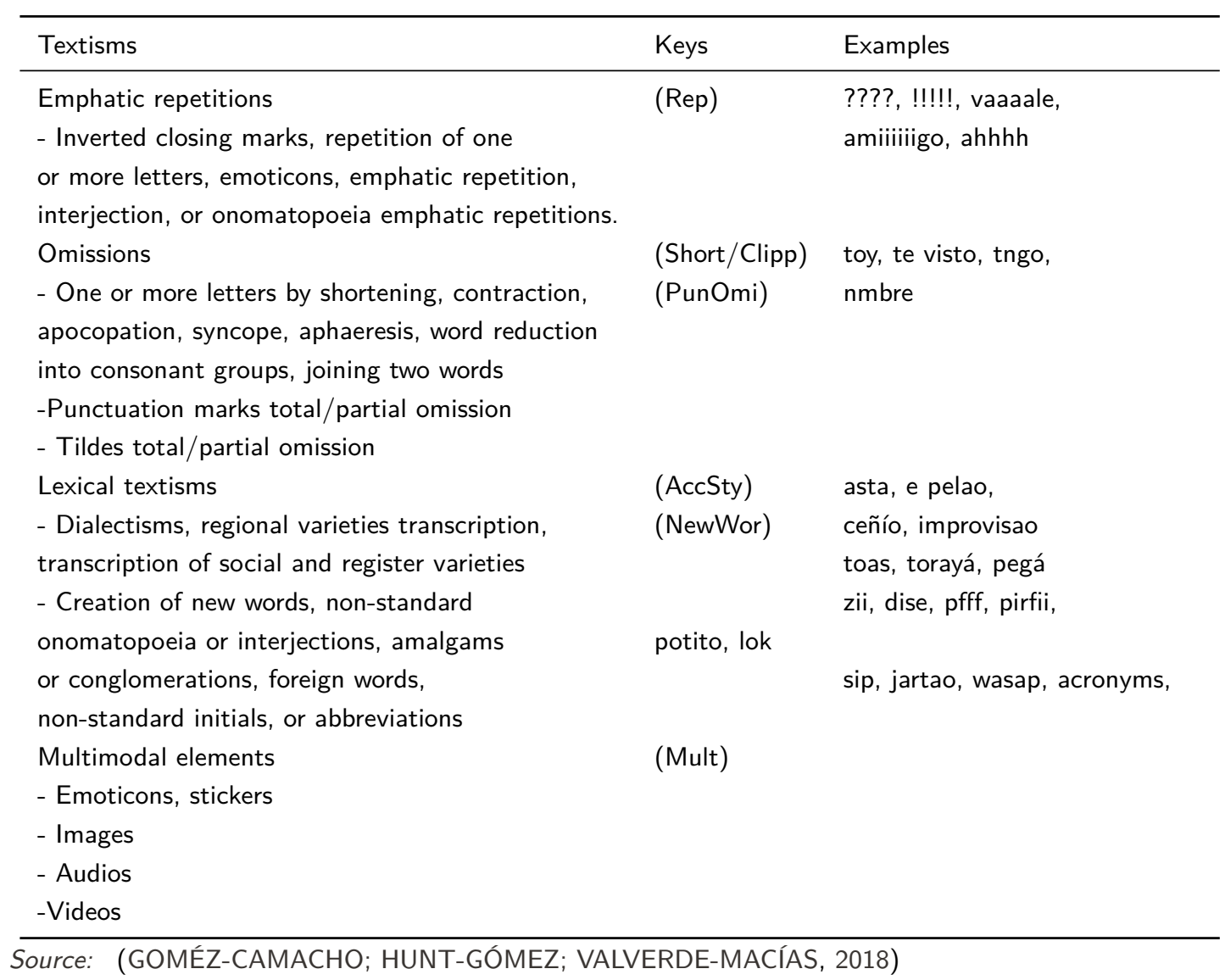

\subsection{Textisms, education and linguistic competence}

Generally, the new written norm used in IM is considered a threat to Spanish standard writing, due partly to the allegedly negative repercussions on student writing outcomes at schools and universities (DE JONGE; KEMP, 2012; DROUIN; DRIVER, 2014; JOHNSON, 2015; THURLOW; POFF, 2013). However, a number of studies have challenged that assertion. Several studies for the English language and the links between digital norm and linguistic competence proved that use of IM had no prejudicial effects (BUSHNELL; KEMP; MARTIN, 2011; DROUIN, 2011; GANN; BARTOSZUK; ANDERSON, 2010; KEMP; BUSHNELL, 2011; PLESTER; WOOD; JOSHI, 2009; POWELL; DIXON, 2011; WOOD et al., 2014). Also, Verheijen, Spooren, and Kemenade (2020) concluded that use of language in social networks improved written competence when examined in Dutch students from different education levels. Also, Bouillaud, Chanquoy, and Gombert (2007), Bernicot et al. (2014), Lanchantin, SimoësPerlant, and Largy (2014), and Cougnon et al. (2017) proved that the use of IM does not negatively affect the standard norm in the case of French.

Research into digital writing is limited, as are studies exploring the digital norm and education in the Latin American context. On the other hand, there appears to be an increase in the number of studies regarding the educational influences of digital writing in Spain (CREMADES et al., 2019; LLOPIS-SUSIERRA; ANDRÉS-SEBASTIÁ, 2020). These studies generally showed a negative perception of the influence textisms had on standard writing and the acquisition of linguistic competence by teenagers (GOMÉZ-CAMACHO; HUNT-GÓMEZ; VALVERDE-MACÍAS, 2018; HUNT-GÓMEZ; NÚÑEZ-ROMÁN; GÓMEZ-CAMACHO, 2020). Paradoxically, this happened even in those cases where the use of IM in the classroom was regarded as positive (CREMADES et al., 2019; LLOPISSUSIERRA; ANDRÉS-SEBASTIÁ, 2020). In the case of the different varieties of Spanish spoken in South America, research has mainly focused on two aspects: the use of IM as a pedagogical tool (ESCOBAR-MAMANI; GÓMEZ-ARTETA, 2020; GONZÁLEZ-SAMÉ; ROMERO-ROMERO, 2019), and the transformation seen in some higher education contexts due to the use of textese (VEYTIABUCHELI; GÓMEZ-GALÁN; VERGARA, 2020). In their study Escobar-Mamani and Gómez-Arteta 
(2020) showed that Peruvian teenagers' use of WhatsApp as a didactic resource improved their written expression. However, the authors noticed a weakness in the tool, namely that grammatical and spelling errors were found in the messages.

Therefore, most of the research addressing digital norm perception and its influence on the acquisition of linguistic competence has focused on the orthographic elements of Peninsular, that is, European Spanish. Consequently, very little is currently known about this phenomenon and its impact in the development of orthographic competence in Latin America, where the largest number of Spanish-speakers live. Hence, this study explores this phenomenon in relation to pre-service teachers of Spanish in the Latin American context, as they should be aware of the increasing influence of the digital norm in standard writing and how it will affect their future teaching practices.

\section{Methods}

The study used a transactional approach. Data were collected in one session. It is based on surveys and uses and applies a descriptive non-experimental design.

\subsection{Objectives}

The main aims of this study were the following: 1) to determine the perception of pre-service teachers of Spanish in Chile and Argentina regarding the written norm of texts sent through their smartphones or shared in social media; 2) to determine their opinion of the impact of textism use on the orthographic competence of secondary education students; 3 ) to compare the results with those of previous research to determine if there were variances in the perception of textisms within the different varieties of the Spanish language.

\subsection{Sample}

The participants of the study were undergraduates in Education Sciences at six of the main universities in Chile and three in Argentina. A simple random samplek was taken ( $N=266$ students, 162 from Chile and 104 from Argentina). A non-probability convenience sample was used (SABARIEGO PUIG, 2004), as subjects were selected through previously established contact with staff members at the different universities or with lecturers, who disseminated the questionnaires among the students.

At the time data were polled, all participants were pre-service teachers of Spanish. The average age of the subjects was 24.48 years, with 41 (14.42\%) males and 255 (84.58\%) females. 98.12\% of the participants stated that they used IM applications, such as WhatsApp, on a daily basis, and only three of the subjects $(1.12 \%)$ reported using them occasionally. A similar proportion was found regarding the use of social networks, used by $95.01 \%$ of the participants. Also, $86.84 \%$ of the subjects indicated that their use of textisms in their text messages and social networks (Facebook, Twitter, Instagram, etc.) varied depending on the person to whom the message was addressed.

\subsection{Rating scale}

A scale called 'Textisms and Written Norm in Spanish Teaching' was used. It was based on the categorisation included in (Table 1) and contained 39 items (37 items with a Likert scale format) and addressed the perceptions of pre-service teachers of Spanish in Chile and Argentina. This scale had been validated and applied to a similar sample of pre-service teachers of Spanish at universities in Spain (GOMÉZ-CAMACHO; HUNT-GÓMEZ; VALVERDE-MACÍAS, 2018). The rating scale was individually administered to the subjects in December 2020 and January 2021 using Google Forms. There was no time restriction when completing it.

The scale contained three dimensions established a priori (GOMÉZ-CAMACHO; HUNT-GÓMEZ; VALVERDE-MACÍAS, 2018), and each of them approached the perception of the textisms used in Spanish from three different angles. In Dimension 1, which dealt with orthographic mistakes and textisms, participants were asked whether the textisms included in (Table 1) were orthographic mistakes when written in text messages in Spanish. In Dimension 2, dealing with textism use and its repercussions for education, participants were asked if they considered whether textisms caused errors in secondary education students' formal texts. Finally, in Dimension 3, participants self-reported the 
rate of recurrence in their use of each of the textisms included in the taxonomy.

The rating scale has been proven valid at both theoretical and empirical levels. Theoretically, it has been validated by the above-mentioned studies. Empirically, the validity of the rating scale was determined by the Multidimensional Scaling-PROXSCAL. The validity of each of the dimensions established a priori was determined using a Cronbach's alpha that reached a value for the whole scale of 0.89, which is considered highly positive (BORG; GROENEN; MAIR, 2013; O'HARE, 1980).

The validity of the scale scored values close to zero when measuring the stress statistical data, and the values for Dispersion Accounted For, DAF and Tucker's coefficient of congruence (TCC) scored close to one (Table 2). Also, internal consistency of each dimension scored values over 0.90 . To sum up, results regarding the empirical validity of the instrument can be considered optimal.

Table 2. Psychometric indicators (reliability and validity) referred to the rating scale.

\begin{tabular}{lccc}
\hline Dimension & $\begin{array}{c}\text { Cronbach's } \\
\text { alpha }\end{array}$ & Imbalance measurements & $\begin{array}{c}\text { Adjustment } \\
\text { measures }\end{array}$ \\
\hline $\begin{array}{l}\text { D1. Links between } \\
\text { textisms and } \\
\text { orthographical } \\
\text { mistakes }\end{array}$ & 0.898 & $\begin{array}{c}\text { NRS Stress I Stress II S-Stress } \\
0.00170 .04120 .0160 .0019\end{array}$ & $\begin{array}{c}\text { DAF TCC } \\
0.99830 .9992\end{array}$ \\
$\begin{array}{l}\text { D2. Textisms use } \\
\text { educational } \\
\text { repercussions. }\end{array}$ & 0.931 & 0.00190 .04350 .06000 .0019 & 0.99810 .9991 \\
$\begin{array}{l}\text { D3. Textisms use in } \\
\text { text messages }\end{array}$ & 0.844 & 0.00550 .07390 .14890 .0069 & 0.99450 .9973 \\
\hline : own elaboration. & & & \\
\hline a Normalised Raw Stress. & & & \\
\end{tabular}

\section{Results}

\subsection{Perception of textisms}

Table 3 and Table 4 include a summing-up of the main descriptive statistical data obtained for each of the three dimensions that integrate the study. The comparison by countries referring to the links between textisms and orthographic mistakes (Dimension 1) showed a higher degree of association of the digital norm with orthographic mistakes in formal writing for the Spanish language among the participants in Chile $(\bar{x}=3.59)$ than for those in Argentina $(\bar{x}=2.99)$, the latter being closer to disagreement when textisms are considered orthographic mistakes. This trend was exacerbated for those textisms that intentionally contrary to orthographic rules (items 9, 10,11, 12, and 14), while it decreased for those that presented no relation to standard orthographic rules (items $7,13,15$ and 16). These results indicated that participants in the study were less conservative regarding acceptance of new digital writing norms when compared to the participants of the study undertaken for Spain $(\bar{x}=3.83)$. Thus, Latin American participants were closer to accepting a new digital norm divergent from those enshrined by the Spanish Royal Academy of Language (RAE) and the Association of Academies of the Spanish Language (ASALE).

Results obtained for Dimension 2 are consistent with those of Dimension 1 . They showed a negative perception of the digital norm from the pedagogical perspective. In this case, participants in Chile also achieved a higher score $(\bar{x}=3.60)$ than those in Argentina $(\bar{x}=3.05)$. Again, Latin American speakers proved to be more innovative in the educational sphere than their equivalent European preservice teachers of Spanish (Table 4). According to pre-service teachers of Spanish, the textisms that were more prejudicial to the learning of the standard orthographic norm were textisms intentionally contrary to the orthographic rules (items $9,10,11$, and 14).

In apparent contradiction with the moderate rejection of textisms identified in the normative 
Table 3. Descriptive statistical data referring to the variables of Dimension 1.

\begin{tabular}{lcccc}
\hline \multicolumn{5}{c}{ Links between textisms and orthographical mistakes average } \\
\hline & Chile & Argentina & Total Latin America & Spain (1) \\
Rep item 7 & 3.02 & 2.15 & 2.68 & 3.52 \\
Short/Clipp item 8 & 3.90 & 2.99 & 3.54 & 4.07 \\
PunOmi item 9 & 4.14 & 3.74 & 3.98 & 4.11 \\
AccOmi item 10 & 4.40 & 3.91 & 4.21 & 4.24 \\
CapOmi. item 11 & 4.11 & 3.70 & 3.95 & 4.30 \\
NonstSpell item 12 & 4.04 & 3.41 & 3.80 & 4.31 \\
Symb/Numb item 13 & 3.65 & 2.94 & 3.38 & 3.98 \\
AccSty item 14 & 4.23 & 3.70 & 4.03 & 4.42 \\
NewWor item 15 & 3.13 & 2.15 & 2.75 & 3.66 \\
Mult item 16 & 1.33 & 1.21 & 1.29 & 1.70 \\
\hline
\end{tabular}

Source: (GOMÉZ-CAMACHO; HUNT-GÓMEZ; VALVERDE-MACÍAS, 2018)

Table 4. Descriptive statistical data referring to the variables of Dimension 2.

\begin{tabular}{lcccc}
\hline \multicolumn{5}{c}{ Textisms use educational repercussion average } \\
\hline & Chile & Argentina & Total Latin America & Spain (1) \\
Missp/Text item 5 & 3.83 & 3.22 & 3.59 & 3.52 \\
Rep item 7 & 3.62 & 2.81 & 3.30 & 4.07 \\
Short/Clipp item 8 & 3.67 & 3.00 & 3.41 & 4.11 \\
PunOmi item 9 & 4.12 & 3.63 & 3.93 & 4.24 \\
AccOmi item 10 & 4.22 & 3.77 & 4.05 & 4.30 \\
CapOmi. item 11 & 3.92 & 3.38 & 3.71 & 4.31 \\
NonstSpell item 12 & 3.82 & 3.25 & 3.60 & 3.98 \\
Symb/Numb item 13 & 3.45 & 2.77 & 3.18 & 4.42 \\
AccSty item 14 & 4.05 & 3.53 & 3.85 & 3.66 \\
NewWor item 15 & 3.24 & 2.44 & 2.93 & 1.70 \\
Mult item 16 & 1.72 & 1.36 & 1.58 & 3.52 \\
\hline
\end{tabular}

Source: (GOMÉZ-CAMACHO; HUNT-GÓMEZ; VALVERDE-MACÍAS, 2018)

Note: Key: Missp/Text: Missp/Text: textisms cause orthographic mistakes. Item 5 
and pedagogical spheres, participants acknowledged that they employed textisms in their own texts (Chile $\bar{x}=3.00$; Argentina $\bar{x}=2.81$ ), as seen in Table 5. This paradox was even more prominent among speakers of the European variant $(\bar{x}=3.27)$, who reported using textisms frequently despite being the most conservative group. According to the results obtained for Dimensions 1 and 2, the most frequently used textisms are those that generate less rejection from a normative and pedagogical perspective (items 17,18 , and 26). Consequently, those textisms that are associated with orthographic mistakes and limitations in the development of the orthographic competence for secondary education studies are the ones (items 19,20,21, 22, and 23) less frequently used.

Table 5. Descriptive statistical data referring to the variables of Dimension 3.

\begin{tabular}{lcccc}
\hline \multicolumn{5}{c}{ Textisms use average } \\
\hline & Chile & Argentina & Total Latin America & Spain (1) \\
Rep item 17 & 3.94 & 3.82 & 3.89 & 3.98 \\
Short/Clipp item 18 & 3.27 & 3.08 & 3.20 & 3.63 \\
PunOmi item 19 & 2.85 & 2.78 & 2.82 & 3.27 \\
AccOmi item 20 & 2.51 & 2.09 & 2.35 & 3.13 \\
CapOmi. item 21 & 2.46 & 2.31 & 2.40 & 2.73 \\
NonstSpell item 22 & 2.77 & 2.37 & 2.61 & 3.01 \\
Symb/Numb item 23 & 2.56 & 2.36 & 2.48 & 3.06 \\
AccSty item 24 & 2.13 & 1.87 & 2.03 & 2.48 \\
NewWor item 25 & 2.88 & 2.98 & 2.92 & 3.08 \\
Mult item 26 & 4.62 & 4.46 & 4.56 & 4.42 \\
\hline
\end{tabular}

Source: (GOMÉZ-CAMACHO; HUNT-GÓMEZ; VALVERDE-MACÍAS, 2018)

\subsection{Correlations between textisms}

To established correlations between textisms, Pearson's product-moment correlation coefficient $(N=$ $\left.266,{ }^{*} p<.05,{ }^{* *} p<.01\right)$ was applied to each of the three dimensions to examine the possible links between variables considering the whole of the sample, without distinguishing between the two countries. The data for each dimension, as well as how they correlate, are examined in the following sections.

\subsection{Textisms and orthographic mistakes}

Firstly, for Dimension 1 and its variables, which relate to the connection between textisms and orthographic mistakes, the presence of correlations among all the variables of the dimension was observed Table 6. It follows that all participants considered that, for the group of variables included in Dimension 1 , all the different types of textisms presented were orthographic mistakes. This is consistent with the previous statements used to describe the main descriptive statistical data for Dimension 1 . The use of multimodal elements (Mult, item 16) should have a different consideration, as it showed the lowest correlation of the textisms considered orthographic mistakes, with the scored value of $\bar{x}=1.29$, which differentiates it from the other textisms as being the only type not identified as a writing mistake. These results fully coincide with the results of the study undertaken in Spain (GOMÉZ-CAMACHO; HUNT-GÓMEZ; VALVERDE-MACÍAS, 2018), so they confirm the existence of a moderate association between textisms and orthographic mistakes in a large part of the Spanish-speaking world (Argentina, Chile, and Spain).

\subsection{Textisms and orthographic competence}

Similar to Dimension 1, all variables from Dimension 2, which referred to the influence of textisms on orthographic competence of secondary education students, presented correlations among them. The analysed data showed that participants considered that the use of textisms by secondary education students could cause orthographic mistakes in their academic texts (Table 7). 
Table 6. Correlation matrix representing Pearson's $r$ between variables for Dimension 1 'Links between textisms and orthographical mistakes' $\left(N=266,{ }^{*} p<.05,{ }^{* *} p<.01\right)$.

\begin{tabular}{|c|c|c|c|c|c|c|c|c|c|c|}
\hline \multicolumn{11}{|c|}{ Dimension 1} \\
\hline & Missp/ & Rep & Short/ & Pun & Acc & Cap & Nonst & Symb/ & Acc & New \\
\hline & Text & 7 & /Clipp & Omi & Omi & Omi & Spell & Numb & Sty & Wor \\
\hline Rep & $.159 * *$ & & & & & & & & & \\
\hline Short/Clipp & $.361 * *$ & $.567^{* *}$ & & & & & & & & \\
\hline PunOmi & $.275^{* *}$ & $.466^{* *}$ & $.644^{* *}$ & & & & & & & \\
\hline AccOmi & $.244 * *$ & $.370 * *$ & $.543^{* *}$ & $.590 * *$ & & & & & & \\
\hline CapOmi & $.259 * *$ & $.447^{* *}$ & $.613^{* *}$ & $.642 * *$ & $.699 * *$ & & & & & \\
\hline NonstSpell & $.321 * *$ & $.555^{* *}$ & $.710^{* *}$ & $.570 * *$ & $.502 * *$ & $.631^{* *}$ & & & & \\
\hline Symb/Numb & $.311^{* *}$ & $.594 * *$ & $.733^{* *}$ & $.536 * *$ & $.477^{* *}$ & $.614^{* *}$ & $.780 * *$ & & & \\
\hline AccSty & $.341^{* *}$ & $.371^{* *}$ & $.638^{* *}$ & $.578^{* *}$ & $.594 * *_{n}$ & $.659 * *$ & $.683^{* *}$ & $.665^{* *}$ & & \\
\hline NewWor & $.298 * *$ & $.534^{* *}$ & $.554^{* *}$ & $.481^{* *}$ & $.472 * *$ & $.466^{* *}$ & $.600 * *$ & $.644 * *$ & $.516 * *$ & \\
\hline Mult 16 & $.161^{* *}$ & .075 & $.176^{* *}$ & $.192^{* *}$ & $.130 *$ & $.186^{* *}$ & $.222 * *$ & $216 * *$ & $.208 * *$ & $.327^{* *}$ \\
\hline
\end{tabular}

Source: own elaboration.

The correlation levels among variables were generally medium/high, and higher than those found in Dimension 1. Therefore, the data indicated that participants in the study perceived orthographic mistakes in academic formal text written by teenagers in secondary education to be the main problem of the digital norm. Again, the use of emoticons, images, audio or videos (Mult) was considered the type of textism least influential on the production of formal texts.

These results are coherent with those from Goméz-Camacho, Hunt-Gómez, and Valverde-Macías (2018) for Spain. Consequently, according to the data, pre-service teachers of Spanish in Argentina, Chile, and Spain share the perception of textisms as an obstacle to the development of the orthographic competence of teenagers.

Table 7. Correlation matrix representing Pearson's $r$ between variables for Dimension 2 'Textism use educational repercussion' $\left(N=266,{ }^{*} p<.05, * * p<.01\right)$.

\begin{tabular}{|c|c|c|c|c|c|c|c|c|c|c|}
\hline \multicolumn{11}{|c|}{ Dimension 2} \\
\hline & Missp/ & Rep & Short/ & Pun & Acc & Cap & Nonst & Symb/ & Acc & New \\
\hline & Text & 7 & /Clipp & Omi & Omi & Omi & Spell & Numb & Sty & Wor \\
\hline Rep & $.505^{* *}$ & & & & & & & & & \\
\hline Short/Clipp & $.527^{* *}$ & $.770 * *$ & & & & & & & & \\
\hline PunOmi & $.411^{* *}$ & $.646^{* *}$ & $.736^{* *}$ & & & & & & & \\
\hline AccOmi & $.405^{* *}$ & $.567^{* *}$ & $.608^{* *}$ & $.790 * *$ & & & & & & \\
\hline CapOmi & $.429 * *$ & $.620 * *$ & $.672^{* *}$ & $.721^{* *}$ & $.757^{* *}$ & & & & & \\
\hline NonstSpell & $.467^{* *}$ & $.659 * *$ & $.718^{* *}$ & $.625 * *$ & $.620 * *$ & $.698 * *$ & & & & \\
\hline Symb/Numb & $.432 * *$ & $.674 * *$ & $.720 * *$ & $.602 * *$ & $.585^{* *}$ & $.679 * *$ & $.810 * *$ & & & \\
\hline AccSty & $.446^{* *}$ & $.540 * *$ & $.616^{* *}$ & $.661^{* *}$ & $.687^{* *}$ & $.660 * *$ & $.707^{* *}$ & $.601^{* *}$ & & \\
\hline NewWor & $.330 * *$ & $.584^{* *}$ & $.583^{* *}$ & $.453 * *$ & $.500 * *$ & $.557 * *$ & $.643^{* *}$ & $.718^{* *}$ & $.530 * *$ & \\
\hline Mult & $.205^{* *}$ & $.243^{* *}$ & $.331^{* *}$ & $.267 * *$ & $.254 * *$ & $.238 * *$ & $.283^{* *}$ & $.356^{* *}$ & $.289 * *$ & $.448 * *$ \\
\hline
\end{tabular}

Source: own elaboration.

The significant correlation between the variables of Dimensions 1 and 2 (except Mult, item 16) confirms the previous results for a great part of the Spanish-speaking world (Table 8). The more textisms are perceived as orthographic mistakes, the more they are considered a negative influence on students' linguistic competence. 
Table 8. Correlation matrix representing Pearson's $r$ between variables for Dimensions 1 . 'Links between textisms and orthographical mistakes' and 2 'Textisms use educational repercussion' $\left(N=266,{ }^{*} p<.05\right.$, $* * p<.01)$.

\begin{tabular}{|c|c|c|c|c|c|c|c|c|c|c|c|}
\hline \multicolumn{12}{|c|}{ Dimension 1} \\
\hline & Missp/ & Rep & Short/ & Pun & Acc & Cap & Nonst & Symb/ & Acc & New & Mult \\
\hline & Text 5 & 7 & /Clipp8 & Omi9 & Omi10 & Omi11 & Spell12 & Numb13 & Sty 14 & Wor15 & 16 \\
\hline Missp/ & $.159 * *$ & $.361 * *$ & $.275^{* *}$ & $.244 * *$ & $.259 * *$ & $.321^{* *}$ & $.311^{* *}$ & $.341 * *$ & $.298 * *$ & $.161^{* *}$ & \\
\hline \multicolumn{12}{|l|}{ Texts } \\
\hline Rep & $.505^{* *}$ & $.369 * *$ & $.431^{* *}$ & $.360 * *$ & $.328 * *$ & $.373^{* *}$ & $.417 * *$ & $.416 * *$ & $.345^{* *}$ & $.332 * *$ & $.137^{*}$ \\
\hline Short/Clipp & $.527 * *$ & $.292 * *$ & $.552 * *$ & $.394 * *$ & $.334 * *$ & $.388 * *$ & $.446 * *$ & $.468 * *$ & $.390 * *$ & $.359 * *$ & $.221^{* *}$ \\
\hline PunOmi & $.411^{* *}$ & $.187^{* *}$ & $.467^{* *}$ & $.499 * *$ & $.429 * *$ & $.401^{* *}$ & $.370 * *$ & $.396 * *$ & $.449 * *$ & $.320 * *$ & $.214^{* *}$ \\
\hline AccOmi & $.405 * *$ & $.191 * *$ & $.438 * *$ & $.357^{* *}$ & $.589 * *$ & $.457^{* *}$ & $.448 * *$ & $.458 * *$ & $.485 * *$ & $.360 * *$ & $.169 * *$ \\
\hline CapOmi & $.429 * *$ & $.272^{* *}$ & $.474 * *$ & $.387 * *$ & $.481^{* *}$ & $.610 * *$ & $.477^{* *}$ & $.459 * *$ & $.524 * *$ & $.354^{* *}$ & $.197^{* *}$ \\
\hline NonstSpell & $.467^{* *}$ & $.271^{* *}$ & $.447^{* *}$ & $.370 * *$ & $.369 * *$ & $.461^{* *}$ & $.553 * *$ & $.500 * *$ & $.467 * *$ & $.418^{* *}$ & $.183^{* *}$ \\
\hline Symb/Numb & $.432 * *$ & $.296 * *$ & $.441^{* *}$ & $.326 * *$ & $.347^{* *}$ & $.450 * *$ & $.465 * *$ & $.578 * *$ & $.415^{* *}$ & $.433^{* *}$ & $.260 * *$ \\
\hline AccSty & $.446 * *$ & $.129 *$ & $.404 * *$ & $.348 * *$ & $.421^{* *}$ & $.394 * *$ & $.410 * *$ & $.388 * *$ & $.662 * *$ & $.353^{* *}$ & $.231^{* *}$ \\
\hline NewWor & $.330 * *$ & $.307 * *$ & $.348 * *$ & $.228 * *$ & $.344^{* *}$ & $.336 * *$ & $.450 * *$ & $.451 * *$ & $.357 * *$ & $.617^{* *}$ & $.312^{* *}$ \\
\hline Mult & $.205^{* *}$ & .104 & $.192 * *$ & $.193 * *$ & $.187^{* *}$ & $.177^{* *}$ & $.185^{* *}$ & $.221 * *$ & $.181^{* *}$ & $.309 * *$ & $.630 * *$ \\
\hline
\end{tabular}

Source: own elaboration.

\subsection{Textisms use}

Correlations for Dimension 3 failed to provide useful data for the purpose of this study, except for multimodal elements (Mult, item 26), which presented a lower correlation degree with the other textisms (Table 9). That indicates that participants use this type of textism in their IM, even if they do not use the others with the same frequency, which is coherent with the score the item received in the descriptive statistical data for the entire sample $(\bar{x}=4.6)$, far above the scores of the other textisms (see (Table 5).

Table 9. Correlation matrix representing Pearson's $r$ between variables for Dimension 3 'Textisms use' ( $N=$ 266. $\left.{ }^{*} p<.05 .{ }^{* *} p<.01\right)$.

\begin{tabular}{|c|c|c|c|c|c|c|c|c|c|}
\hline \multicolumn{10}{|c|}{ Dimension 3} \\
\hline & Rep & Short/ & Pun & Acc & Cap & Nonst & Symb/ & Acc & New \\
\hline & 17 & Clipp18 & Omi19 & Omi20 & Omi21 & Spell22 & Numb23 & Sty24 & Wor25 \\
\hline Short/Clipp & $.382 * *$ & & & & & & & & \\
\hline PunOmi & $.222^{* *}$ & $.489 * *$ & & & & & & & \\
\hline AccOmi & $.263^{* *}$ & $.470 * *$ & $.567^{* *}$ & & & & & & \\
\hline CapOmi & $.209 * *$ & $.352^{* *}$ & $.448 * *$ & $.505^{* *}$ & & & & & \\
\hline NonstSpell & $.201^{* *}$ & $.454^{* *}$ & $.382 * *$ & $.374^{* *}$ & $.422 * *$ & & & & \\
\hline Symb/Numb & $.178^{* *}$ & $.447^{* *}$ & $.378 * *$ & $.430 * *$ & $.385 * *$ & $.572^{* *}$ & & & \\
\hline AccSty & $.195 * *$ & $.384^{* *}$ & $.432 *$ & $.393 * *$ & $.408 * *$ & $.558 * *$ & $.493 * *$ & & \\
\hline NewWor & $.299 * *$ & $.295^{* *}$ & $.382 * *$ & $.265^{* *}$ & $.342 * *$ & $.453^{* *}$ & $.268^{* *}$ & $.388 * *$ & \\
\hline Mult 26 & $.353^{* *}$ & $.161^{* *}$ & .102 & $.142^{*}$ & .087 & $.179 * *$ & $.119 * *$ & .095 & $.246^{* *}$ \\
\hline
\end{tabular}

Source: own elaboration.

Another noteworthy aspect of the Dimension 3 variables is the negative correlation between 'NewWord' and 'Mult' with those variables of Dimensions 1 and 2 (Table 10. It follows that participants who used those words, that is, onomatopoeic or exclamatory expressions diverging from the norm, foreign words or acronyms, and also emoticons, images, audios, or videos, tended to consider the use of textisms less as orthographic mistakes. Also, those participants showed a lower perception of the prejudicial influence of textisms on secondary students' formal texts.

These results are consistent with those obtained by the Spanish study (GOMÉZ-CAMACHO; HUNT-GÓMEZ; VALVERDE-MACÍAS, 2018). Therefore, it can be concluded that the use of ne- 
ologisms in IM and, mostly, the use of non-verbal multimodal elements does not conflict with the linguistic or pedagogical sphere, according to pre-service teachers of Spanish, regardless of nationality.

Table 10. Correlation matrix representing Pearson's $r$ between variables 'NewWord' and 'Mult' from Dimension 3 and Dimension 1 'Links between textisms and orthographical mistakes' and Dimension 2 'Textisms use educational repercussions' $\left(N=266 .{ }^{*} p<.05 .{ }^{* *} p<.01\right)$.

\begin{tabular}{lccccccccccc}
\hline \multicolumn{10}{c}{ Dimension 1 } \\
\hline & Rep & Short/ & Pun & Acc & Cap & Nonst & Symb/ & Acc & & Mult \\
& 17 & Clipp18 & Omi19 & Omi20 & Omi21 & Spell22 & Numb23 & Sty24 & Wor25 & 16 \\
D3. NewWor 25 & $-.139^{*}$ & $-.182^{* *}$ & $-.205^{* *}$ & -.074 & $-.134^{* *}$ & $-.163^{*}$ & -.108 & -.091 & $-.137^{*}$ & $.122^{*}$ \\
D3. Mult 26 & -.086 & .067 & -.004 & -.019 & -.009 & .011 & .009 & .056 & -.008 & -.092 \\
\hline & & & \multicolumn{1}{c}{ Dimension 2 } & & & & & \\
\hline D3. NewWor 25 & $-.147^{*}$ & $-.136^{*}$ & -.103 & -.070 & $-.163^{* *}$ & $-.148^{*}$ & -.095 & -.089 & -.072 & .103 \\
D3. Mult 26 & .002 & .052 & .036 & .042 & .033 & .044 & .022 & .085 & .045 & -.029 \\
\hline
\end{tabular}

Source: own elaboration.

Finally, another noteworthy feature related to Dimension 3 was participant age. A negative correlation was established between the age variable of the participants and all variables of Dimension 3 (Table 11). That means that the younger the participant, the greater the use of textisms. This is particularly marked in the use of multimodal elements or images (Mult) $(p=-2.17)$. No significant differences were found between male and female subjects.

Table 11. Correlation matrix representing Pearson's $r$ between variable age and Dimension 3 'Textisms use' $\left(N=266,{ }^{*} p<.05, * * p<.01\right)$.

\begin{tabular}{rccccccccc}
\hline \multicolumn{10}{c}{ Dimension 3 } \\
\hline Rep & Short/ & Pun & Acc & Cap & Nonst & Symb/ & Acc & New & Mult \\
& Clipp & Omi & Omi & Omi & Spell & Numb & Sty & Wor & \\
Age,$- 153^{*}$ &,- 099 &,- 083 &,$- 133^{*}$ &,$- 134^{*}$ &,$- 230^{* *}$ &,- 048 &,$- 162^{* *}$ &,- 063 &,$- 217^{* *}$ \\
\hline
\end{tabular}

Source: own elaboration.

\section{Discussion}

With regard to Chile and Argentina, and the perception among pre-service teachers of Spanish of the written norm used in mobile mediated communication and its relationship with standard writing, the results show a clear association between textism use and orthographical mistakes in the academic context. This tendency was more apparent the more the textisms diverged from the orthographic rules, as those textisms contrary to the norm were given the lowest values by the subjects of the study. These data are consistent with previous studies by Goméz-Camacho, Hunt-Gómez, and ValverdeMacías (2018) and by Cremades et al. (2019), which focused on in-service and pre-service teachers. Both studies proved that orthographic and punctuation mistakes typical of the digital norm could be extensively transferred into any language use context.

Nonetheless, participants stated that they regularly used textisms in IM. It is remarkable that those textisms that reported a higher frequency of use among pre-service teachers were those that provoked a minor degree of rejection from a pedagogical perspective and which were less divergent from the standard norm. Along the same line, textisms associated with orthographic mistakes presented a lower frequency of use (GOMÉZ-CAMACHO; NÚÑEZ-ROMÁN; PERERA-RODRÍGUEZ, 2016; GOMÉZCAMACHO; HUNT-GÓMEZ; VALVERDE-MACÍAS, 2018).

A strong link was established between use of textisms and their impact on the orthographic competence of secondary education students. Textisms intentionally contrary to academic norms received lower values from a didactic point of view and were considered to be harmful to the development of teenagers' orthographic competence. This finding is contrary to previous studies for English (KEMP; 
BUSHNELL, 2011) and French (BERNICOT et al., 2014; COUGNON et al., 2017); it has been suggested that textisms are not a threat to the acquisition of linguistic competence in either of those languages.

Even if all textisms were, in practice, perceived to be orthographical mistakes and prejudicial to the development of Spanish orthographic competence, multimodal textisms were considered part of the digital norm and were less frequently perceived to be mistakes (GOMÉZ-CAMACHO; HUNT-GÓMEZ; VALVERDE-MACÍAS, 2018).

In relation to this identified greater tolerance of multimodal textisms, a group of participants showing a lower perception of textisms as orthographic errors and considering them to be less prejudicial to orthography was detected. That group was, as a matter of fact, made up of those pre-service teachers of Spanish who self-reported regular use of multimodal elements and digital neologisms, textisms that do not interfere with the academic rules and which cannot be deemed unacceptable in an educational context.

A clear difference was established between the use of textisms made by the subjects of the study and their perception of the impact of textisms use on teenagers' development of orthographic competence. It means that pre-service teachers of Spanish use textisms regularly in their IM while believing that it does not affect their orthography. At the same time, they consider that use of textisms by secondary education students could lead those students to make orthographic mistakes in their formal texts. These results corroborate the trend observed in previous studies (BOUILLAUD; CHANQUOY; GOMBERT, 2007; GOMÉZ-CAMACHO; NÚÑEZ-ROMÁN; PERERA-RODRÍGUEZ, 2016; GOMÉZ-CAMACHO; HUNT-GÓMEZ; VALVERDE-MACÍAS, 2018; PLESTER; WOOD; BELL, 2008; VÁZQUEZ-CANO; MENGUAL-ANDRÉS; ROIG-VILA, 2015), which showed that the negative consideration of textisms used is generally attributed to younger people, omitting the practices of older users. In this sense, it must be highlighted that the youngest participants of the study, regardless of their country of origin, showed a tendency to use a wider variety of textisms in their messaging, especially intense in the use of multimodal elements, as observed in previous studies (PLESTER; WOOD; BELL, 2008; POWELL; DIXON, 2011; GOMÉZ-CAMACHO; HUNT-GÓMEZ; VALVERDE-MACÍAS, 2018). This negative perception shown by pre-service teachers of Spanish regarding the impact of the use of textisms on teenagers' orthographic competence highlights a weakness in teacher-training, also identified by Cremades et al. (2019), namely a belief among participants that the increasing influence of IM should be valued and given a relevant position in compulsory education.

Even if results are similar for the different varieties of Spanish examined, some small variations were observed. Participants in Argentina were less conservative in their perception of textisms as orthographic mistakes when compared with those in Chile, and even less so when compared with pre-service teachers in Spain. Generally speaking, pre-service teachers of Spanish in Chile perceived textisms in a similar way to their counterparts in Spain as regards their negative influence on orthography. However, Argentinian subjects were more receptive to the coexistence of new elements belonging to the digital norm alongside the academic norm.

Together with Spanish participants, Chilean subjects were the most conservative, which corroborates the linguistic conception of the countries analysed. Chile has a linguistic culture founded on the premise that Peninsular Spanish is pre-eminent, as is the authority of institutions such as the Spanish Royal Academy of Language (ROJAS, 2012). Linguistic beliefs of pre-service teachers of Spanish from Chile are based on the concepts of unity and pan-hispanic correctness. Data regarding the Argentinian participants are consistent with some studies which indicated that speakers not only rejected this sole linguistic model, but also recognised different centres as transmitters of the norm and defended linguistic diversity as an enriching element (LLULL; PINARDI, 2014; GUTIÉRREZ BOHMER; BORZI, 2018).

Finally, it is paradoxical that speakers of the European variant of Spanish, who more negatively valued textisms and their influence on formal texts, were the ones presenting the higher frequency of use of textisms. However, Argentinian pre-service teachers of Spanish, who reported a minor use of textisms in their IM, were those who showed a higher degree of tolerance of the digital norm. 


\section{Conclusions}

This study regarding Argentinian and Chilean pre-service teachers' perception of the digital norm and the impact it has on teenagers' acquisition of orthographical competence led to some interesting results. Firstly, pre-service teachers of Spanish presented a negative perception of textism use. They also considered that using textisms is harmful to the development of the orthographic competence of teenagers, even if participants recognised using textisms regularly while believing that such use does not negatively impact their own writing when the standard norm is required.

Secondly, a clear differentiation between those textisms that deviated from the academic norm and those that did not clash with the linguistic or the pedagogical sphere, such as neologisms and multimodal elements. The ones in the first group were less frequently used and were considered to be a possible source of mistakes in teenagers' texts. In the second group, multimodal elements and neologisms were considered a minor threat to teenagers' linguistic acquisition and reported a higher use among pre-service teachers of Spanish.

Thirdly, the study allowed us to determine disparities between the perceptions of pre-service teachers of Spanish in Chile and Argentina. Participants in Chile showed a more negative perception of textisms and their impact on teenagers than did their counterparts in Argentina, and the former were closer to the position of pre-service teachers of Spanish in Spain, who are the most conservative in their rejection of the digital norm. Paradoxically, those who reported using more textisms in their IM (subjects in Spain and Chile), presented a higher negative perception of the impact of textism use on secondary students' orthographic competence. Argentinian pre-service teachers, who self-reported a lower use of textisms in IM, showed less rejection of the consequences of their use.

This study has shed some light on the difficulties arising from the interaction of the digital norm and the standard written norm in the educative context for pre-service teachers of Spanish in Argentina, Chile, and Spain, even though they have received their education in a digital context. In spite of that, a greater tolerance is envisaged regarding some textisms, such as multimodal elements and digital neologisms, which could come to be a meeting point between the digital and the standard norms, and, therefore, foster an environment in which the difficulties posed by their complicated coexistence are overcome. In this regard, the training of pre-service teachers of Spanish should emphasise the coexistence of the digital and standard norms and devote more attention to digital writing in the classroom so as to improve the negative perception of pre-service teachers of Spanish of the impact of textism use on teenagers' orthographic competence.

\section{Source of funding}

This research has been funded by the Department of Economy, Knowledge, Business and University of the Autonomous Community of Andalusia (Spain), in the framework of the Incentives to Research Groups PAI (Call 2019), reference 2019/HUM529.

\section{References}

ALONSO, Elena; PEREA, Manuel. SMS: impacto social y cognitivo. Escritos de psicología, v. 2, n. 1, p. 24-31, 2008. Available from: <https://scielo.isciii.es/scielo.php?script=sci_arttext\&pid=S198938092008000300004\&lng=es\&nrm=iso\&tlng=es >. Visited on: 4 July 2021.

ANDROUTSOPOULOS, Jannis; BUSCH, Florian. Digital punctuation as an interactional resource: the message-final period among German adolescents. Linguistics and Education, v. 62, p. 100871, 2021. DOI: https://doi.org/10.1016/j.linged.2020.100871. Visited on: 4 July 2021.

BERNICOT, Josie et al. How do skilled and less-skilled spellers write text messages? A longitudinal study. Journal of Computer Assisted Learning, v. 30, n. 6, p. 559-576, 2014. DOI: 10.1111/jcal.12064.

BETTI, S. La jerga juvenil de los SMS. Cuadernos del Lazarillo, v. 31, p. 68-76, 2006.

BORG, Ingwer; GROENEN, Patrick J. F; MAIR, Patrick. 2013. ed. [S.I.]: Springer, 2013.

BOUILLAUD, Céline; CHANQUOY, Lucile; GOMBERT, Jean-Emile. Cyberlangage et orthographe : quels effets sur le niveau orthographique des élèves de CM2, 5e et 3e ? Bulletin de psychologie, Numéro 492, n. 6, p. 553, 2007. DOI: $10.3917 /$ bupsy.492.0553. 
BUSHNELL, Catherine; KEMP, Nenagh; MARTIN, Frances Heritage. Text-messaging practices and links to general spelling skill: A study of australian children. Australian Journal of Educational and Developmental Psychology, v. 11, n. 03, p. 27-38, 2011.

CALERO, Maria Luisa. El Discurso del Whatsapp: entre el Messenger y el SMS. Oralia, v. 17, p. 85-114, 2014.

CANTAMUTTO, Lucía. Aperturas y cierres en la interacción digital escrita. Tonos digital: Revista de estudios filológicos, n. 37, p. 14, 2019. Available from:

<http://www.tonosdigital.es/ojs/index.php/tonos/article/view/2246/1072>. Visited on: 4 July 2021.

CANTAMUTTO, Lucía. Variación y adaptabilidad: los tratamientos en la comunicación por SMS en español bonaerense. Onomázein. Revista de lingüística, filología y traducción, add 04, p. 01-25, 2018. DOI:

10.7764/onomazein.add.04.

CANTAMUTTO, Lucía; VELA DELFA, Cristina. Emojis frecuentes en las interacciones por whatsapp. Círculo de Lingüística Aplicada a la Comunicación, v. 77, 0 SE - Artículos, Feb. 2019. DOI: 10.5209/CLAC.63282.

CANTAMUTTO, Lucía; VELA DELFA, Cristina. Fórmulas de tratamiento en la mensajería instantánea: mecanismos de apelación en las conversaciones escritas de dos variedades de español. Onomázein. Revista de lingüística, filología y traducción, add 05, p. 142-160, 2018. DOI: 10.7764/onomazein.add.05.

CAURCEL DÍAZ, Andrés; Î̃̃IGUEZ DEL RÍO, Yovan; GÓMEZ HIDALGO, José. Un método de análisis de lenguaje tipo SMS para el castellano. Linguamática, v. 5, n. 1, p. 31-39, 2013. DOI: 10.21814/Im.5.1.156.

CHEVALIER, Stéphanie. ¿Qué tan popular es WhatsApp en Latinoamérica? [S.I.: s.n.], 2019.

CORPORACIÓN LATINOBARÓMETRO. Informe 2018. [S.I.: s.n.], 2018. Available from:

<https://www.latinobarometro.org/latContents.jsp>. Visited on: 4 July 2021.

COUGNON, Louise Amelie et al. Social media, spontaneous writing and dictation. Spelling variation. Journal of French Language Studies, v. 27, n. 3, p. 309-327, Nov. 2017. DOI: 10.1017/S095926951600020X.

CREMADES, Raúl et al. The influence of mobile instant messaging in language education: perceptions of current and future teachers. Interactive Learning Environments, Routledge, 2019. DOI:

10.1080/10494820.2019.1612451.

CRYSTAL, David. Txting the gr8 db8. [S.I.]: Oxford university press, 2008.

DE JONGE, Sarah; KEMP, Nenagh. Text-message abbreviations and language skills in high school and university students. Journal of Research in Reading, v. 35, n. 1, p. 49-68, Feb. 2012. DOI:

10.1111/j.1467-9817.2010.01466.x.

DOMÍNGUEZ CUESTA, Carmela. El lenguaje de los SMS y del chat en las aulas. Cuadernos de pedagogía, n. 343, p. 65-69, 2005.

DROUIN, Michelle; DRIVER, Brent. Texting, textese and literacy abilities: A naturalistic study. Journal of Research in Reading, v. 37, n. 3, p. 250-267, 2014. DOI: 10.1111/j.1467-9817.2012.01532.x.

DROUIN, Michelle A. College students' text messaging, use of textese and literacy skills. Journal of Computer Assisted Learning, v. 27, n. 1, p. 67-75, 2011. DOI: 10.1111/j.1365-2729.2010.00399.x.

ESCOBAR-MAMANI, Fortunato; GÓMEZ-ARTETA, Indira. WhatsApp for the development of oral and written communication skills in Peruvian adolescents. Comunicar, v. 28, n. 65, p. 111-120, 2020. DOI: 10.3916/C65-2020-10.

FLORES-SALGADO, Elizabeth; CASTINEIRA-BENITEZ, Teresa A. The use of politeness in WhatsApp discourse and move 'requests'. Journal of Pragmatics, v. 133, p. 79-92, 2018. DOI:

10.1016/j.pragma.2018.06.009.

GALÁN RODRÍGUEZ, Carmen. En los arrabales de la comunicación: los mensajes SMS. Anuario de estudios filológicos, n. 25, p. 103-117, 2002.

GANN, Rosalind Raymond; BARTOSZUK, Karin; ANDERSON, Jillian H. If u txt 2 much, duz it mean u cant spell. International Journal of the Book, v. 7, n. 2, p. 69-78, 2010. DOI:

10.18848/1447-9516/cgp/v07i02/36807.

GIRALDO GIRALDO, Camilo; RÍOS LONDOÑO, Dora Miryam; CARDONA CIFUENTES, Fabio Andrés. La gramática al margen de la norma: la escritura en WhatsApp. Lenguaje, v. 46, n. 2, p. 311, 2018. DOI:

10.25100/lenguaje.v46i2.6585. 
GOMÉZ-CAMACHO, Alejandro. La ortografía del español y los géneros electrónicos. Comunicar, v. 15, n. 29, p. 157-164, 2007. DOI: https://doi.org/10.3916/26025. Visited on: 4 July 2021.

GOMÉZ-CAMACHO, Alejandro; HUNT-GÓMEZ, Coral Ivy; VALVERDE-MACÍAS, Andrés. Textisms, texting, and spelling in Spanish. Lingua, v. 201, p. 92-101, 2018. DOI:

https://doi.org/10.1016/j.lingua.2017.09.004. Visited on: 4 July 2021.

GOMÉZ-CAMACHO, Alejandro; LOPES, Antonio. Texting, textisms and teaching Portuguese. Porta Linguarum. Revista Interuniversitaria de Didáctica de las Lenguas Extranjeras, Monográfico II, p. 43-55, 2017. DOI: https://doi.org/10.30827/digibug.54108. Visited on: 4 July 2021.

GOMÉZ-CAMACHO, Alejandro; NÚÑEZ-ROMÁN, Francisco; PERERA-RODRÍGUEZ, Víctor Hugo. Testismi, messaggistica e didattica dell'italiano: percezioni degli studenti universitari. Cadmo, v. 2, n. 2016, p. 57-74, 2016. DOI: http://dx.doi.org/10.3280/Cad2016-002006. Visited on: 4 July 2021.

GONZÁLEZ-SAMÉ, Héctor; ROMERO-ROMERO, Jhison E. Incidencia de las redes sociales en el proceso de escritura de los estudiantes universitarios. In: AGUADED, I.; VIZCAÍNO VERDÚ, A.; SANDOVAL ROMERO, Y. (Eds.). Competencia mediática y digital: Del acceso al empoderamiento. [S.I.]: Grupo Comunicar, 2019. p. 75-84.

GUTIÉRREZ BOHMER, Sofía; BORZI, Claudia. Beliefs and attitudes of young Rioplatense university students towards the educated varieties of Spanish. Boletin de Filología, v. 53, n. 2, p. 263-292, 2018. ISSN 07189303. DOI: $10.4067 /$ s0718-93032018000200263.

HUNT-GÓMEZ, Coral I.; NÚÑEZ-ROMÁN, Francisco; GÓMEZ-CAMACHO, Alejandro. Textisms and spelling. Perception of pedagogy students of the $Z$ generation. Formacion Universitaria, v. 13, n. 2, p. 143-152, 2020. DOI: 10.4067/S0718-50062020000200143.

JOHNSON, Genevieve Marie. The Invention of Reading and the Evolution of Text. Journal of Literacy and Technology, v. 16, n. 1, p. 107-128, 2015.

KEMP, Nenagh; BUSHNELL, Catherine. Children's text messaging: Abbreviations, input methods and links with literacy. Journal of Computer Assisted Learning, v. 27, n. 1, p. 18-27, 2011. DOI:

10.1111/j.1365-2729.2010.00400.x.

KEMP, Nenagh; GRACE, Abbie. Txting across time: undergraduates' use of 'textese' in seven consecutive first-year psychology cohorts. Writing Systems Research, v. 9, n. 1, p. 82-98, 2017. DOI:

10.1080/17586801.2017.1285220.

LANCHANTIN, Tonia; SIMOËS-PERLANT, Aurélie; LARGY, Peirre. Good spellers write more textism than bad spellers in instant messaging: The case of French. PsychNology Journal, v. 12, n. 1-2, p. 45-63, 2014.

LLISTERRI, Joaquim. Marcas fonéticas de la oralidad en la lengua de los chats: elisiones y epéntesis consonánticas. Revista de Investigación Lingüística, v. 5, n. 2, p. 61-100, 2002.

LLOPIS-SUSIERRA, Mireia; ANDRÉS-SEBASTIÁ, María de El Puig. La ortografía en las redes sociales y los chats: una nueva herramienta de aprendizaje entre los adolescentes. Tonos digital: Revista de estudios filológicos, v. 38, p. 1-23, 2020.

LLULL, Gabriela; PINARDI, Lilián Carolina. Actitudes lingüísticas en la Argentina. El español en Buenos Aires: Una aproximación a las representaciones de sus hablantes. Bergen Language and Linguistics Studies, v. 5, n. 0, 2014. DOI: 10.15845/bells.v5i0.676.

LYDDY, Fiona et al. An analysis of language in university students' text messages. Journal of Computer-Mediated Communication, v. 19, n. 3, p. 546-561, 2014. DOI: 10.1111/jcc4.12045.

MANCERA RUEDA, Ana. Usos lingüísticos alejados del español normativo como seña de identidad en las redes sociales. Bulletin of Spanish Studies, v. 93, n. 9, p. 1469-1493, 2016. DOI:

10.1080/14753820.2016.1181435.

MARTín, Rosa. La conversación guasap. Pragmática Sociocultural / Sociocultural Pragmatics, v. 4, n. 1, p. 108-134, 2016. DOI: 10.1515/soprag-2015-0010.

MAS ÁLVAREZ, Inmaculada; ZAS VARELA, Luz. De lo necesario a lo inevitable: casi dos décadas de código SMS. In: CUM corde et in nova grammatica: estudios ofrecidos a Guillermo Rojo. [S.I.: s.n.], 2012. p. 585-595.

O'HARE, David. An Introduction to the Concepts and Methods of Multidimensional Scaling. British Educational Research Journal, v. 6, n. 1, p. 29-42, 1980. DOI: 10.1080/0141192800060104. 
PLESTER, Beverly; WOOD, Clare; BELL, Victoria. Txt msg n school literacy: Does texting and knowledge of text abbreviations adversely affect children's literacy attainment? Literacy, v. 42, n. 3, p. 137-144, 2008. DOI: $10.1111 /$ j.1741-4369.2008.00489.x.

PLESTER, Beverly; WOOD, Clare; JOSHI, Puja. Exploring the relationship between children's knowledge of text message abbreviations and school literacy outcomes. British Journal of Developmental Psychology, v. 27, n. 1, p. 145-161, 2009. DOI: 10.1348/026151008X320507.

POWELL, Daisy; DIXON, Maureen. Does SMS text messaging help or harm adults' knowledge of standard spelling? Journal of Computer Assisted Learning, v. 27, n. 1, p. 58-66, 2011. DOI:

10.1111/j.1365-2729.2010.00403.x.

ROJAS, Darío. Actitudes lingüísticas de hispanohablantes de santiago de chile: Creencias sobre la corrección idiomática. Onomazein, v. 26, n. 2, p. 69-93, 2012.

SABARIEGO PUIG, Marta. La investigación educativa: génesis, evolución y características. In: RAFAEL, Bizquerra Alzina (Ed.). Metodología de la investigación educativa. [S.I.]: La Muralla, 2004. p. $52-87$.

THURLOW, Crispin. Generation Txt ? The sociolinguistics of young people 's text-messaging. Discourse Analysis Online, v. 1, p. 1-31, 2003. Available from:

<http://extra.shu.ac.uk/daol/articles/v1/n1/a3/thurlow2002003-paper.html>. Visited on: 4 July 2021.

THURLOW, Crispin; POFF, M. The language of text-messaging. In: HERRING, S.C.; STEIN, D.;

VIRTANEN, T. (Eds.). Handbook of the Pragmatics of CMC. [S.I.]: Mouton de Gruyter, 2013. p. 163-190.

TURNER, Kristen Hawley. Digitalk: A new literacy for a digital generation. Phi Delta Kappan, v. 92, n. 1, p. 41-46, 2010. DOI: 10.1177/003172171009200106.

TURNER, Kristen Hawley et al. Demystifying digitalk: The what and why of the language teens use in digital writing. Journal of Literacy Research, v. 46, n. 2, p. 157-193, 2014. DOI: 10.1177/1086296X14534061.

VÁZQUEZ-CANO, Esteban; MENGUAL-ANDRÉS, Santiago; ROIG-VILA, Rosabel. Análisis lexicométrico de la especificadad de la escritura difital del adolescente en WhatsApp. RLA. Revista de lingüística teórica y aplicada, v. 53, n. 1, p. 83-105, 2015. DOI: 10.4067/s0718-48832015000100005.

VERHEIJEN, Lieke; SPOOREN, Wilbert; KEMENADE, Ans van. Relationships between Dutch Youths' Social Media Use and School Writing. Computers and Composition, v. 56, p. 1-26, 2020. DOI:

10.1016/j.compcom.2020.102574.

VEYTIA-BUCHELI, María Guadalupe; GÓMEZ-GALÁN, José; VERGARA, Diego. Presence of new forms of intercultural communication in higher education: Emojis and social interactions through whatsapp among graduate students. Education Sciences, v. 10, n. 11, p. 1-17, 2020. DOI: 10.3390/educsci10110295.

WALDRON, Sam; WOOD, Clare; KEMP, Nenagh. Use of predictive text in text messaging over the course of a year and its relationship with spelling, orthographic processing and grammar. Journal of Research in Reading, v. 40, n. 4, p. 384-402, 2017. DOI: 10.1111/1467-9817.12073.

WOOD, Clare et al. Grammatical understanding, literacy and text messaging in school children and undergraduate students: A concurrent analysis. Computers \& Education, v. 70, p. 281-290, Jan. 2014. DOI: 10.1016/j.compedu.2013.09.003. Available from:

<https://linkinghub.elsevier.com/retrieve/pii/S036013151300256X>. Visited on: 4 July 2021.

\section{Author contributions}

Francisco Núñez-Román: Conceptualization, Investigation, Supervision, Writing - review and editing, Visualization; Alejandro Gómez-Camacho: Conceptualization, Methodology, Validation, Formal analysis, Writing - review and editing; Juan Antonio Núñez-Cortés: Investigation, Data curation, Writing - review and editing; María Constanza Errázuriz-Cruz: Investigation, Data curation, Writing - review and editing . 